\section{Postharvest Carbon Dioxide Treatment Enhances Firmness of Several Cultivars of Strawberry}

\author{
R.B. Smith and L.J. Skog \\ Horticultural Research Institute of Ontario, Vineland Station, Ont. \\ LOR 2E0, Canada \\ Additional index words. firmness enhancement, oxygen, pH, Hunter color, Fragaria \\ xananassa
}

\begin{abstract}
Various cultivars of strawberry (Fragaria xananassa Duch.) were stored for $42 \mathrm{~h}$ under an atmosphere of $15 \% \mathrm{CO}_{2}$ to determine whether their firmness would be enhanced. Compared to initial samples and stored control samples, enhanced firmness was found in 21 of the 25 cultivars evaluated. The $\mathrm{CO}_{2}$ had no effect on color, as measured by Hunter ' $L$ ', ' $a$ ' and 'b', or on soluble solids concentration (SSC) or $\mathbf{p H}$. There were significant differences among cultivars in firmness; Hunter color ' $L$ ', ' $a$ ', and 'b'; SSC; and $\mathbf{p H}$.
\end{abstract}

Research conducted in Poland (Ptocharski, 1982) and in Canada (Smith, 1992) has shown that the firmness of some cultivars of strawberry is enhanced when they are stored in a modified atmosphere high in $\mathrm{CO}_{2}$. The concentration of $\mathrm{O}_{2}$ had no effect on firmness. Other researchers have indicated that $\mathrm{CO}_{2}$ helps maintain firmness (Harris and Harvey, 1973; Li and Kader, 1989) or that fruit stored in a $\mathrm{CO}_{2}$ atmosphere is firmer than berries not stored under $\mathrm{CO}_{2}$. It is possible that enhancement of firmness has not been identified because comparisons between treated and nontreated fruit may only have been made at the end of the storage trial and because it has been assumed that the differences were due to firmness retention rather than firmness enhancement. The fruit of some cultivars of strawberry may not respond to a $\mathrm{CO}_{2}$-enriched atmosphere.

The objective of this investigation was to test whether controlled-atmosphere (CA) storage enhances the firmness of various cultivars and selections of strawberry.

Twenty-five cultivars of strawberry were harvested from experimental plots (Horticultural Research Institute of Ontario, Vineland Station) as they became mature during the season. Within cultivars, berries of similar color were selected and then randomized among the three treatments (initial, air-stored, and CA-stored). The replicates consisted of three successive harvests from each cultivar. The fruit was forced-air-cooled to $0.5 \mathrm{C}$ and placed in polyethylene storage units (Smith and Reyes, 1988), and the atmospheres were

Received for publication 18 Nov. 1991. Accepted for publication 2 Jan. 1992. We thank J. Nichols for technical assistance and Brian Allen (Univ. of Guelph) for statistical assistance and acknowledge the monetary support from The Ontario Berry Growers' Assn., Louth Niagara Orchards, and The Agriculture and Food Research Fund. The cost of publishing this paper was defrayed in part by the payment of page charges. Under postal regulations, this paper therefore must be hereby marked advertisement solely to indicate this fact. adjusted with compressed gases and a Nova 305 portable $\mathrm{CO}_{2}-\mathrm{O}_{2}$ analyzer (Nova Analytical Systems, Hamilton, Ont). The $\mathrm{CO}_{2}$ was maintained at $0 \%$ or $15 \%$ and $\mathrm{O}_{2}$ at $18.5 \%$ for both. The berries were held under these atmospheres for $42 \mathrm{~h}$. Trials conducted with 'Redcoat' have shown an increasing response throughout a 30- to 45-h exposure to $\mathrm{CO}_{2}$; however, other trials with 'Redcoat' have shown no increase in response after 18 h (Smith, 1992).

Upon removal from the CA storage, the berries were evaluated for firmness. Firmness was measured as the force required to initiate cell shearing (Voisey et al., 1972) (generally referred to as the bioyield point or puncture test) when the berry was probed with a $0.64-\mathrm{cm}$ flat-tip probe affixed to an Ottawa Texture Measuring System (Model D.1804.C; Canners Machinery, Simcoe, Ont.). Measurements were recorded on 15 berries from each treated sample.

A 200-g sample of fruit from each treatment was washed, blot dried, decapped, and frozen $(-35 \mathrm{C})$ for subsequent determinations of $\mathrm{pH}$ (model 811; Orion Research, Boston); soluble solids concentration (SSC) (AO Abbe refractometer model 10450; American Optical Corp., Buffalo, N.Y.); and Hunter color 'L', 'a', and 'b' (Hunterlab D253A Color Difference Meter; Hunter Associates Lab., Fairfax, Va.). The samples for color were blended under vacuum to provide uniform, bubble-free material. A 50-g sample was placed in an Agtron sample cup (\#11595; Magnuson Engineers, San Jose, Calif.) and the color read through the bottom using reflected light. The final standardization of the Hunter meter was made on the red tile (' $L$ ' $=25.9$, ' $a$ ' $=28.4$, and ' $b$ ' = 12.9). [Hunter ' $L$ ' measures lightness/darkness $(0=$ black, $100=$ white $)$, 'a' measures $\mathrm{red} /$ green $(+=\mathrm{red}, 0=$ grey, $-=$ green), 'b' measures blue/yellow ( $+=$ yellow, $0=$ grey, $-=$ blue)].

A randomized complete-block design was used in this trial. Analysis of variance (ANOVA) was conducted using an IBM PST
Model 50 computer with the Statistical Analysis System (SAS) program package (SAS Institute, Cary, N.C.). Means within cultivars were separated using Duncan's multiple range test. The firmness data was subjected to a $\log _{10}$ transformation to correct for lack of homogeneity of variances. The standard error was calculated for variables used to evaluate changes among cultivars. Correlation coefficients were calculated for various combinations of ' $\mathrm{L}$ ', ' $a$ ', and ' $b$ '.

After $42 \mathrm{~h}$, the fruit exposed to $\mathrm{CO}_{2}$ was significantly firmer than initial samples and the non- $\mathrm{CO}_{2}$-treated control berries (Table 1). Comparison of means revealed that 21 of the 25 cultivars treated with $\mathrm{CO}_{2}$ were firmer than the berries samples initially and 21 were firmer than the corresponding control samples. The $\mathrm{CO}_{2}$-treated fruit of 'Chandler' and 'Vantage' were not significantly firmer than the initial or the stored control samples. Other $\mathrm{CO}_{2}$-treated berries not significantly firmer than initial samples, but significantly firmer than the control, were 'Bounty' and ' $V$ 7251-1'. The $\mathrm{CO}_{2}$-treated fruit of 'Kent' and 'Midway' were significantly firmer than the initial samples, but not significantly firmer than the control. In initial trials, $\mathrm{CO}_{2}$-treated fruit was firmer than the control for $\approx 60 \%$

Table 1. Comparison of firmness within strawberry cultivars cooled to $0 \mathrm{C}$ but not stored (initial) or stored at $0 \mathrm{C}$ for $42 \mathrm{~h}$ either in air or controlled atmosphere $\left(15 \% \mathrm{CO}_{2}\right.$ and $\left.18 \% \mathrm{O}_{2}\right)$.

\begin{tabular}{|c|c|c|c|}
\hline \multirow[b]{2}{*}{ Cultivar } & \multicolumn{3}{|c|}{ Firmness $(\mathrm{N})$} \\
\hline & Initial & $\begin{array}{l}\text { Control- } \\
\text { stored }\end{array}$ & CA-stored \\
\hline Allstar ${ }^{z, y}$ & $6.92 \mathrm{a}$ & $6.70 \mathrm{a}$ & $9.46 \mathrm{~b}$ \\
\hline Bounty & $4.34 \mathrm{ab}$ & $4.02 \mathrm{a}$ & $4.99 \mathrm{~b}$ \\
\hline Chandler & $6.31 \mathrm{a}$ & $6.47 \mathrm{a}$ & 7.29 \\
\hline Dana & $4.16 \mathrm{a}$ & $4.59 \mathrm{a}$ & $5.41 \mathrm{t}$ \\
\hline Glooscap & $5.05 \mathrm{a}$ & $4.86 \mathrm{a}$ & $.03 \mathrm{~b}$ \\
\hline Governor Simcoe & $6.17 \mathrm{a}$ & $6.12 \mathrm{a}$ & $8.09 \mathrm{~b}$ \\
\hline Guardian & $5.09 \mathrm{a}$ & $4.71 \mathrm{a}$ & 6.12 \\
\hline GU62E55 & $3.55 \mathrm{a}$ & $3.56 \mathrm{a}$ & $4.79 \mathrm{~b}$ \\
\hline Kent & $5.79 \mathrm{a}$ & $6.28 \mathrm{ab}$ & 7.2 \\
\hline Mic & $4.95 \mathrm{a}$ & $4.99 \mathrm{a}$ & $6.31 \mathrm{~b}$ \\
\hline Mid & $4.65 \mathrm{a}$ & $5.22 \mathrm{ab}$ & 50 \\
\hline & $6.71 \mathrm{a}$ & $6.82 \mathrm{a}$ & $8.28 \mathrm{~b}$ \\
\hline & $4.80 \mathrm{a}$ & $4.73 \mathrm{a}$ & $6.75 \mathrm{~b}$ \\
\hline & $4.90 \mathrm{a}$ & $5.24 \mathrm{a}$ & $7.16 \mathrm{~b}$ \\
\hline & $8.22 \mathrm{a}$ & $7.91 \mathrm{a}$ & $11.48 \mathrm{~b}$ \\
\hline & $5.06 \mathrm{a}$ & $4.63 \mathrm{a}$ & $7.28 \mathrm{~b}$ \\
\hline & $2.88 \mathrm{a}$ & $2.98 \mathrm{a}$ & $4.14 \mathrm{~b}$ \\
\hline & $6.15 \mathrm{a}$ & $6.50 \mathrm{a}$ & $8.04 \mathrm{~b}$ \\
\hline $\mathrm{Tri}$ & $6.08 \mathrm{a}$ & $5.90 \mathrm{a}$ & \\
\hline $\mathrm{Va}$ & $6.31 \mathrm{a}$ & $6.24 \mathrm{a}$ & $6.90 \mathrm{a}$ \\
\hline & $4.84 \mathrm{a}$ & $4.80 \mathrm{a}$ & $6.81 \mathrm{~b}$ \\
\hline $\mathrm{Ve}$ & $3.41 \mathrm{a}$ & $3.24 \mathrm{a}$ & $4.19 \mathrm{~b}$ \\
\hline Vibrant & $4.58 \mathrm{a}$ & $4.69 \mathrm{a}$ & $6.21 \mathrm{~b}$ \\
\hline Selkirk & $9.40 \mathrm{a}$ & $8.83 \mathrm{a}$ & $12.65 \mathrm{~b}$ \\
\hline Scotland & $9.02 \mathrm{ab}$ & $8.34 \mathrm{a}$ & $10.30 \mathrm{~b}$ \\
\hline $\mathrm{Me}$ & 5.57 & 5.53 & 7.21 \\
\hline SE & 1.05 & $\cdots$ & $\cdots$ \\
\hline
\end{tabular}

Error mean square 0.00124

Error d.f.

${ }^{z}$ Means within rows separated by Duncan's multiple range test, $P=0.05$. Actual data are presented, analysis of variance conducted using $\log _{10}$ $\mathrm{X}$.

yFirmness measured as the force required to initiate cell shearing (puncture test) using a $0.64-\mathrm{cm}$, flat-tip probc.

'A Univ. of Guelph selection. 
Table 2. Hunter color ' $\mathrm{L}$ ', ' $\mathrm{a}$ ', and ' $\mathrm{b}$ '; $\mathrm{pH}$; and soluble solids concentration (SSC) for various strawberry cultivars in production trials at the Horticultural Research Institute of Ontario.

\begin{tabular}{|c|c|c|c|c|c|}
\hline \multirow[b]{2}{*}{ Cultivar } & \multicolumn{3}{|c|}{ Hunter color $^{2}$} & \multirow[b]{2}{*}{$\mathrm{pH}$} & \multirow{2}{*}{$\begin{array}{c}\text { SSC } \\
(\%) \\
\end{array}$} \\
\hline & ' $\mathrm{l}$ ' & 'a' & 'b' & & \\
\hline Allstar & 26.14 & 34.24 & 13.40 & 3.48 & 7.07 \\
\hline Bounty & 20.42 & 30.44 & 10.35 & 3.55 & 7.93 \\
\hline Chandler & 20.86 & 32.70 & 11.33 & 3.21 & 6.54 \\
\hline Dana & 26.95 & 34.92 & 12.74 & 3.40 & 7.93 \\
\hline Glooscap & 20.53 & 31.25 & 10.86 & 3.52 & 6.80 \\
\hline Governor Simcoe & 28.46 & 33.93 & 13.72 & 3.51 & 7.57 \\
\hline Guardian & 27.07 & 33.42 & 12.64 & 3.49 & 7.60 \\
\hline GU62E55' & 19.48 & 31.17 & 10.55 & 3.33 & 7.40 \\
\hline Kent & 20.83 & 30.16 & 10.63 & 3.39 & 7.07 \\
\hline Micmac & 25.68 & 33.08 & 12.48 & 3.50 & 7.67 \\
\hline Midway & 24.06 & 34.36 & 12.81 & 3.26 & 6.20 \\
\hline Pajaro & 25.60 & 34.45 & 12.97 & 3.37 & 6.33 \\
\hline Raritan & 23.18 & 32.84 & 12.12 & 3.57 & 6.33 \\
\hline Redcoat & 27.65 & 34.20 & 13.16 & 3.34 & 6.73 \\
\hline Selva & 25.11 & 31.49 & 11.95 & 3.51 & 5.67 \\
\hline Settler & 24.27 & 33.88 & 12.84 & 3.43 & 6.70 \\
\hline Sparkle & 22.90 & 32.39 & 11.63 & 3.51 & 8.10 \\
\hline Tribute & 24.04 & 32.73 & 11.82 & 3.52 & 6.50 \\
\hline Tristar & 21.30 & 32.66 & 11.47 & 3.27 & 7.23 \\
\hline Vantage & 26.85 & 35.42 & 13.44 & 3.33 & 8.83 \\
\hline Veestar & 25.17 & 34.54 & 13.08 & 3.30 & 6.63 \\
\hline Vesper & 21.20 & 31.81 & 11.35 & 3.56 & 7.13 \\
\hline Vibrant & 22.28 & 33.95 & 12.26 & 3.22 & 6.97 \\
\hline Selkirk & 22.95 & 33.70 & 12.39 & 3.38 & 6.57 \\
\hline Scotland & 28.01 & 33.85 & 12.73 & 3.50 & 8.30 \\
\hline SE & 0.82 & 0.71 & 0.45 & 0.04 & 0.15 \\
\hline Error mean square & 2.021 & 1.531 & 0.604 & 0.0056 & 0.066 \\
\hline Error d.f. & 48 & 48 & 48 & 48 & 48 \\
\hline
\end{tabular}

${ }^{2}$ 'L' (light/dark; $0=$ black and $100=$ white), ' $a$ ' (red/green; $+=$ red, $0=$ grey, - = green), 'b' (blue/yellow; $-=$ blue, $0=$ grey, $+=$ yellow).

${ }^{y} \mathrm{~A}$ Univ. of Guelph selection.

of the cultivars evaluated (R.B.S., unpublished data). The initial trials were conducted using 10 fruit for firmness tests. Sample size was increased to 15 fruit, resulting in less variation among replicates and, thus, more cultivars exhibiting a significant difference between treated and nontreated fruit. It is possible that if 20 fruit had been used, there would have been a significant difference exhibited for all cultivars. Ptocharski (1982) noted that the berries' response to $\mathrm{CO}_{2}$ was affected by stage of development. This could have been another factor having an influence on whether the $\mathrm{CO}_{2}$ significantly increased the firmness of the various cultivars. In this investigation, fruit not fully colored or overripe was discarded, whereas in the initial trials, fruit representing a wider range of development was used.

On average, the treated fruit was $29.5 \%$ firmer than the initial and the nontreated tween the various Hunter readings were all highly significant. As Hunter 'L' decreased, Hunter ' $\mathrm{a}$ ' increased $(r=0.68)$ and Hunter ' $b$ ' decreased $(r=0.83)$. As Hunter ' $a$ ' increased, Hunter 'b' decreased $(r=0.93)$. Morris et al. (1985), using a Gardner Color Difference Meter (CDM), indicated that lower CDM ' $L$ ' values were accompanied by higher CDM ' $a$ ' values and higher anthocyanin content.

Enhancement in firmness of strawberries treated with $\mathrm{CO}_{2}$ provides further justification for the practice of subjecting berries to high levels of $\mathrm{CO}_{2}$ during marketing. If the sole purpose of applying $\mathrm{CO}_{2}$ were for enhancing firmness, then the procedure could be done in a cold room designed for that purpose, rather than applying the $\mathrm{CO}_{2}$ under a pallet wrap as is presently practiced in some production areas of the world. Before any strawberry cultivar is subjected to high levels of $\mathrm{CO}_{2}$ for the sole purpose of enhancing firmness, its response to high levels of $\mathrm{CO}_{2}$ should be evaluated to determine whether there is a benefit. When firmness is enhanced, in soft fruit in particular, the consumer would be the beneficiary of a superiorquality fresh-market berry.

\section{Literature Cited}

Harris, C.M. and J.M. Harvey. 1973. Quality and decay of California strawberries stored in $\mathrm{CO}_{\text {- }}$ enriched atmospheres. Plant Dis. Rptr. 57:4446.

Li, C. and A.A. Kader. 1989. Residual effects of controlled atmospheres on postharvest physiology and quality of strawberries. J. Amer. Soc. Hort. Sci. 114(4):629-634.

Morris, J.R., W.A. Sistrunk, C.A. Sims, and G.L. Main. 1985. Effects of cultivar, postharvest storage, preprocessing dip treatments and style of pack on the processing quality of strawberries. J. Amer. Soc. Hort. Sci. 110(2):172-177.

Ptocharski, W. 1982. Strawberries-Quality of fruits, their storage life and suitability for processing. Part III. Fruit Sci. Rpt. 9(3):111122.

Smith, R.B. 1992. Controlled atmosphere storage of 'Redcoat' strawberry fruit. J. Amer. Soc. Hort. Sci. 117:260-264

Smith, R.B. and A.A. Reyes. 1988. Controlled atmosphere storage of Ontario grown celery. J. Amer. Soc. Hort. Sci. 113(3):390-394.

Voisey, P.W., D.C. MacDonald, M. Kloeck, and W. Foster. 1972. The Ottawa texture measuring system-An operational manual. Eng. Res. Serv., Agr. Canada, Ottawa, Bul. 7024. 